\title{
Exploring the Relationship between Receptive and Productive Vocabulary Sizes and Their Increased Use by Azerbaijani English Majors
}

\author{
Konul Hajiyeva ${ }^{1,2}$ \\ ${ }^{1}$ Department of Linguistics, University of Antwerp, Antwerpen, Belgium \\ ${ }^{2}$ Department of Innovations in Teaching, Azerbaijan University of Languages, Baku, Azerbaijan \\ Correspondence: Konul Hajiyeva, Department of Linguistics, University of Antwerp, Rodestraat 14, 2000 \\ Antwerpen, Belgium. Tel: 32-466-106-714. E-mail: konul.hajiyeva@student.uantwerpen.be; \\ konul_12@rambler.ru
}

Received: April 15, 2015 Accepted: June 26, 2015 Online Published: July 23, 2015

doi:10.5539/elt.v8n8p31 URL: http://dx.doi.org/10.5539/elt.v8n8p31

\begin{abstract}
This article reports on the results of two studies on receptive and productive vocabulary knowledge of first-year English majors in an English-medium degree programme. The aim of the study is to answer these research questions: (1) to what extent do the receptive and productive vocabulary sizes of English majors increase after a year of instruction; (2) what is the ratio between the increases in receptive and productive knowledge; (3) do English majors achieve the expected threshold vocabulary size of 4.000-5.000 word families, after a year of instruction, that will enable them to follow lectures in English? In order to gauge students' receptive and productive vocabulary knowledge, participants in this study - 159 first-year English majors - were given two vocabulary tests at the beginning of their first and second years of study: the Vocabulary Levels Test and the Productive Vocabulary Levels Test. The results indicate that: (1) learners' receptive vocabulary did not expand, whereas their productive vocabulary increased by 21 per cent; (2) their overall receptive vocabulary knowledge was larger than their productive knowledge and the gap between the two narrows after one year; (3) despite having received instruction, after a year, learners still lack the vocabulary threshold to meet their academic needs. Based on these results, the study reflects on the relationship between the content of the teaching materials used in class and the students' vocabulary knowledge. Recommendations aimed at informing teachers about the appropriate steps to take to approach language proficiency teaching are also discussed.
\end{abstract}

Keywords: receptive vocabulary, productive vocabulary, vocabulary size estimates, vocabulary growth, English as foreign language

\section{Introduction}

Learning vocabulary is an essential part of mastering a second or foreign language as considerable evidence points to the high correlation between vocabulary (usually a measure of vocabulary size) and various measures of language proficiency (Nation \& Beglar, 2007; Schmitt, 2010). For example, a close relationship (e.g. correlations of $0.50-0.75$ ) has been shown to exist between vocabulary size and reading comprehension (Laufer, 1992). Furthermore, there is a strong relationship between vocabulary, language proficiency and academic achievement (Milton \& Treffers-Daller, 2013). Considering Alderson's (2005) report on the correlation of vocabulary knowledge with reading at 0.64 , listening from $0.61-0.65$, writing from $0.70-0.90$ and grammar at 0.64 , it is striking that a single factor - vocabulary knowledge - can account for such correlation indicators. However, it should not be assumed that if a learner has sufficient vocabulary then all else is straight forward:

'vocabulary knowledge enables language use, language use enables the increase of vocabulary knowledge and knowledge of the world enables the increase of vocabulary knowledge and language use' (Nation \& Waring, 1997).

Accordingly, if vocabulary knowledge is accepted as a fundamental component of foreign- or second-language (EFL or ESL) proficiency, it is important to assess learners' knowledge of the words (Read, 1997).

With these constraints in mind, information on the estimates of learners' vocabulary size and their significance 
for English as EFL or ESL will help language researchers and teachers to outline clear goals for vocabulary learning. This is because a measurement of the size of vocabulary is important for planning, diagnosis and research (Nation, 2011).

Estimates of the size of the English vocabulary range from half a million to more than two million (Crystal, 1987). This wide range is due to the difficulty scholars have in defining the term 'word', a discrepancy that has led to an observable disparity in the number of known English words. Studies conducted by Goulden, Nation and Read (1990) report on the number of words in English as comprising approximately 54000 'word families' (Note 1), of which an educated and intelligent native speaker would know between 16000 and 20000 (D'Anna, Zechmeister, \& Hall, 1991; Goulden, Nation, \& Read, 1990; Nation \& Waring, 1997).

In contrast to the figures above, the most recent study done by Milton and Treffers-Daller (2013) posits that '[u]niversity level monolingual English speakers arrive at university knowing, on average, about 10000 word families'. This finding shows that vocabulary knowledge of native-speaking university entrants is not as extensive as initially estimated. However, the amount of lexis known by native speakers is still extensive and it is a rather frustrating and demotivating way of setting goals from a foreign-language learner's perspective. It therefore remains beyond what most learners of English can realistically achieve. Yet teachers of English may still find it interesting and beneficial to know the measures of native speakers' vocabulary size in order to identify the extent of the learning task that learners of English have to face.

Fortunately, learners of English do not need to achieve a size of vocabulary equivalent to that of a native speaker in order to use English for various forms of communication (Shmitt, 2010). For example, Laufer (1992) reccommends a vocabulary of approximately 3.000 word families in order to achieve 95 per cent text coverage (Note 2). Nation (2006) maintains that learners need a vocabulary size of about 6.000-7.000 word families if 98 per cent coverage of spoken text is needed, 8.000-9.000 word families for a written text. Laufer and Ravenhorst-Kalovski (2010) calculated that between 4.000 and 5.000 word families are required for 95 per cent text coverage; they consider this threshold as a vocabulary size needed for minimal understanding. This threshold is raised to approximately 8.000 word families for optimal understanding. Learning such a large number of words is one of the main challenges language learners face (Nation, 2006; Schmitt, 2008).

Studies examining the estimates of receptive (reading and listening) and productive (writing and speaking) vocabulary knowledge indicate that vocabulary size estimates of EFL/ESL learners with different language backgrounds range from conservative figures to lower ones (see section 2.1). Moreover, the results also indicate that the growth of receptive vocabulary is more rapid than that of productive vocabulary, and that the gap between the two dimensions of vocabulary knowledge becomes smaller over time (Laufer, 1998; Laufer \& Paribakht, 1998; Zhong \& Hirsh, 2009; Ozturk, 2012). Extending this comparison between receptive and productive vocabulary growth to another group of EFL students will contribute to greater insight into the relationship between the two.

The present study builds on the results of a recent study (Hajiyeva, 2014) which investigated the vocabulary-level needs of first-year English majors at the Azerbaijan University of Languages. Findings from this study indicate that students' receptive and productive vocabulary sizes are small and that their receptive knowledge not only preceeds, but also exceeds, their productive knowledge; the gap, however, between the two is wide. The results also reveal that students enrolled at the university need strong support in vocabulary learning in order to enable them to succeed in their academic studies. Having these results in mind, there was a need to gauge these same learners' vocabulary knowledge after one year of instruction in order to gain insight into the vocabulary development process.

The present study sets out to do this. Consequently, it builds on earlier studies by exploring the receptive and productive vocabulary sizes of Azerbaijani English majors over a period of a single academic year in order to gain insights into the EFL learners' lexical progress (which is still unknown in terms of the ratio between the receptive and productive vocabulary) and to observe whether the gap between the two is narrowed. The study also intends to inform pedagogical thinking in the Azerbaijani case, since, to date, no such study has been conducted.

In the light of the above, the current study seeks to provide language teachers and researchers with empirical data about vocabulary growth, if any, over one academic year representing 210 hours of English language class time in an EFL context. The following research questions will be examined:

1. To what extent do the receptive and productive vocabulary sizes of English majors increase after a year of instruction? 
2. What is the relationship between the receptive and productive vocabulary knowledge growth?

3. Do English majors attain the expected threshold vocabulary size of 4.000-5.000 word families after one year of instruction?

Before presenting the design of the research, I will discuss briefly the research findings on the vocabulary size of ESL and EFL students, the distinction between the students' receptive and productive vocabulary knowledge, and the relationship between the two.

\section{Related Literature}

\subsection{Research on Vocabulary Size and Text Coverage among EFL and ESL Students}

We know a great deal about vocabulary teaching and vocabulary learning from empirical studies. For instance, some learners fail to achieve even moderate vocabulary learning goals. As can be seen from the examples provided in Table 1 below, learners with different language backgrounds (Turkish, Chinese, Serbian, Japanese, Azerbaijani and Hebraic) fail to pass the VLT (N. Schmitt, D. Schmitt \& Clapham, C., 2001). This gives rough estimates of their receptive and productive vocabulary knowledge. The size of the learners' vocabulary knowledge is given in word families, although in the studies marked with an asterisk (see Ozturk, 2012; Danilovic \& Grujic, 2014; Zhong \& Hirsh, 2009), the authors did not provide the total vocabulary size of the participants in terms of reception and production - either in order to serve the purpose of their studies (personal communication) or because of the 'lack of a reliable means of making the calculation' (Zhong \& Hirsh, 2009). Instead, vocabulary frequency profile measures (or mean values for each measured frequency band) were distributed. Nation and Webb (2011) elucidate that, when counting for receptive purposes, it is more competent to count in word families. This is because word family members require little or no additional learning for listening or reading on the part of the learners if they already have a good command of the important affixes of the language. This is the rationale behind counting learners' receptive vocabulary size in word families.

To measure productive vocabulary knowledge, it is advantageous to count learners' knowledge of the words in word types or lemmas (all family members of the same base word) (Nation \& Webb, 2011); however, I decided to count and present the estimates of the previous studies in word families in order to create a basis for direct comparison of the two types of vocabulary knowledge.

Accordingly, the total receptive and productive vocabulary size of these learners was arrived at by calculating the mean scores provided in the studies mentioned below by using Laufer and Ravenhorst-Kalovski's (2010) formula (Note 5).

The studies conducted by Ozturk (2012) and Danilovic and Grujic (2014), where learners were also tested at the 10000 word band as well as for AWL and UWL, were not included in their studies, since the 10000 band and AWL and UWL are not included in the formula suggested by Laufer and Ravenhorst-Kalovski (2010). At the same time, it is too speculative beyond the 5.000 word band, therefore I decided not to include the data from them in the calculations given below (Table 1). My estimates are therefore approximate and are used only in order to give a rough guide as to the extent of non-native English-language learners' vocabulary size - an approximate estimate is better than no estimate at all. In Table 1, the vocabulary size of the learners is given in descending order from the highest to the lowest, according to receptive vocabulary size.

Table 1. A summary of studies focusing on receptive and productive vocabularies

\begin{tabular}{lllll}
\hline Background & $\begin{array}{l}\text { Participants and } \\
\text { learning context } \\
\text { (word families) }\end{array}$ & $\begin{array}{l}\text { Receptive vocabulary } \\
\text { size } \\
\text { (word families) }\end{array}$ & $\begin{array}{l}\text { Productive } \\
\text { vocabulary size } \\
\text { (word families) }\end{array}$ & Study \\
\hline Turkish* & $\begin{array}{l}\text { First-year university } \\
\text { students }\end{array}$ & 4.485 & 3.017 & Ozturk, 2012 \\
Chinese* & $\begin{array}{l}\text { English } \\
\text { secondary-level }\end{array}$ & 3.738 & 2.826 & $\begin{array}{l}\text { Zhong \& Hirsh, } \\
\text { learners }\end{array}$ \\
Serbian* & $\begin{array}{l}\text { First-year English } \\
\text { majors }\end{array}$ & 2.506 & 2.427 & $\begin{array}{l}\text { Danilovic \& } \\
\text { Grujic, 2014 \& } \\
\text { Waring, 1997 }\end{array}$ \\
\hline
\end{tabular}




\begin{tabular}{|c|c|c|c|c|}
\hline & undergraduates & & & \\
\hline Azerbaijani & $\begin{array}{l}\text { First-year } \\
\text { majors }\end{array}$ & 2.091 & 866 & Hajiyeva, 2014 \\
\hline Hebraic & High-school leavers & 1.900 & 1.700 & Laufer, 1998 \\
\hline
\end{tabular}

The vocabulary sizes of the English-language learners with different language backgrounds listed in Table 1 show limited receptive and productive vocabulary knowledge when compared to native speakers' estimates. According to Nation and Waring (1997), native speakers add approximately 1.000 word families a year, whereas Milton and Treffers-Daller (2013) suggest an uptake of 500 word families a year to their vocabulary size. This means that a five-year-old native-speaking English learner beginning school will have a vocabulary of around 4.000 to 5.000 word families. A native-speaking university graduate will have a vocabulary of around 20000 word families (Goulden, Nation, \& Read, 1990).

In contrast, the gap between the vocabulary size of adult EFL learners and that of native speakers is usually very large. This means that many adult EFL learners have a vocabulary comprising far fewer than 5.000 word families (see Table 1) in spite of having studied English for several years (Nation \& Waring, 1997). Interestingly, learners of English as a second language, not as a foreign language (53 European students of advanced proficiency), do achieve vocabulary sizes similar to those of native speakers, but they are not in the majority (Milton \& Meara, 1995).

Table 2 presents a summary of estimates of the receptive and productive vocabulary sizes of learners of English as a foreign language with different language backgrounds after having received certain weeks or year(s) of instruction.

Table 2. A summary of studies focusing on receptive and productive vocabulary growth

\begin{tabular}{|c|c|c|c|c|c|}
\hline Background & $\begin{array}{l}\text { Participants and } \\
\text { learning context }\end{array}$ & $\begin{array}{l}\text { Receptive* } \\
\text { vocabulary size } \\
\text { increase } \\
\text { (word families) }\end{array}$ & $\begin{array}{l}\text { Productive* } \\
\text { vocabulary size } \\
\text { increase } \\
\text { (word families) }\end{array}$ & Time span & Study \\
\hline Turkish* & $\begin{array}{l}\text { First-year } \\
\text { university } \\
\text { students }\end{array}$ & $\begin{array}{l}4.485 \rightarrow 4.587 \\
2 \%\end{array}$ & $\begin{array}{l}3.017 \rightarrow 3.452 \\
14 \%\end{array}$ & 4 years & $\begin{array}{l}\text { Ozturk, } \\
2012\end{array}$ \\
\hline Chinese* & $\begin{array}{l}\text { English } \\
\text { secondary level } \\
\text { learners }\end{array}$ & $\begin{array}{l}3.738 \rightarrow 3.982 \\
7 \%\end{array}$ & $\begin{array}{l}2.826 \rightarrow 3.308 \\
17 \%\end{array}$ & 10 weeks & $\begin{array}{l}\text { Zhong \& } \\
\text { Hirsh, 2009 }\end{array}$ \\
\hline Serbian* & $\begin{array}{l}\text { First-year } \\
\text { English majors }\end{array}$ & $\begin{array}{l}2.506 \rightarrow 2.680 \\
7 \%\end{array}$ & $\begin{array}{l}2.427 \rightarrow 3.202 \\
32 \%\end{array}$ & 1 year & $\begin{array}{l}\text { Danilovic \& } \\
\text { Grujic, } 2014\end{array}$ \\
\hline Hebraic & $\begin{array}{l}\text { High-school } \\
\text { leavers }\end{array}$ & $\begin{array}{l}1.900 \rightarrow 3.500 \\
84 \%\end{array}$ & $\begin{array}{l}1.700 \rightarrow 2.550 \\
50 \%\end{array}$ & 1 year & $\begin{array}{l}\text { Laufer, } \\
1998\end{array}$ \\
\hline
\end{tabular}

* Receptive/productive vocabulary increase is given in word families and percentages.

As Table 2 indicates, non-native speakers' vocabulary does not grow at the same rate as that of native speakers, where the latter add 1.000 word families every year. EFL learners acquire the language in a different setting (i.e. a learning environment) receive less input and have fewer opportunities for meaningful interaction, which results in a slow growth of their vocabulary knowledge. In contrast to this, a study done by Laufer (1998) reports on the optimistic growth of high-school learners' vocabulary knowledge of 1.600 word families (see Table 2, column 3) after one year of instruction. However, Laufer (1998) explains that this growth does not imply that in the preceeding school years the same number of words could have been learnt each year. This observation enables us to say that learning words in another language is a fairly slow and lengthy process. Laufer (1998) also describes the process of learning a foreign language as the 'learner's progress along the interlanguage continuum from a 
non-existent knowledge towards native-like competence without necessarily reaching it'. This process involves a gradual increase in the learner's vocabulary size. This is why investigating the progress of learners' vocabulary size can be of considerable value to language research and teaching.

\subsection{Receptive Versus Productive Mastery of Vocabulary Knowledge}

Melka-Teichroew (1982) has argued about the abundance of terms used to define the notions of receptive and productive knowledge of a language and introduced a range of terms to describe this dichotomy: 'active vocabulary vs. passive; comprehension vs. production; understanding vs. speaking; recognitional vocabulary vs. actual or possible vocabulary use'. From this description, we can see that vocabulary knowledge is multifaceted and contains a number of aspects or dimensions (Schmitt, 2010). Following this, various dimensions (also called 'taxonomies'), namely, 'size' and 'organisation' (related to vocabulary depth) (Meara, 1996); 'partial-precise knowledge', 'depth of knowledge' and 'receptive-productive' (Henriksen, 1999: 304) have been proposed. As stressed by Schmitt (2010) and Melka (1997), these dimensions are useful constructs of lexical competence and there appears to be consensus that vocabulary is investigated and tested on the basis of these dimensions, namely, size, depth and receptive-productive knowledge (Nizonkiza \& Van den Berg, 2014). Today, the dimensional approach to vocabulary knowledge is widely accepted by researchers: among other things, these dimensions do not tell us much about the receptive-productive relationship itself (Schmitt, 2010).

A distinction between receptive and productive vocabulary knowledge is usually made when researchers have to deal with estimating the vocabulary sizes of certain individuals or to compare receptive against productive vocabulary size. The generally accepted assumption underlying this discussion is that in one's lexicon receptive vocabulary is much larger than productive vocabulary and that reception precedes production (Henriksen, 1999; Melka, 1997; Schmitt, 2010). Melka (1997) has seen this relationship between the two as a continuum where gradually increasing knowledge helps one to move from receptive to productive mastery. It is unclear, though, how this process actually happens and the minimum amount of vocabulary that is required before productive knowledge acquisition or growth becomes possible.

To date, there has been little research to inform us on this key issue (Read, 2000; Schmitt, 2010). Meara (1990), contrary to Melka (1997), proposes a different possibility: that the two might be different qualitatively depending on an item's status within the lexical network. He takes a lexical organisation perspective and suggests that there is not a gradual but a clear distinction between these two types of vocabulary knowledge. For example, receptively known vocabulary comprises items which respond to external stimuli only. In other words, one needs to read them in a text or hear them in order to be able to recall them. Conversely, productively known vocabulary does not require an external stimulus, but 'can be activated by other words' (Meara, 1990: 153). This means that the two types of vocabulary knowledge do not rely on identical types of information and depend on different mental processes. This view supports the idea that receptive and productive vocabulary knowledge are to be considered as two different systems and that there is a gap between the two. Concerning the size of the gap between the two, Melka (1997) summarises several tendencies in explaining this disparity:

- Reception is much larger than production.

- The gap between reception and production is narrowed in the learning curve of the learner, although reception still precedes the production. However, later 'the relatively slow development of productive vocabulary is compensated for as it partially catches up'.

- The gap between the two is not significant: the two vocabularies are equal.

From this Melka (1997) tentatively concludes that either one knows a word and uses it or does not know it. He also assumes that there is some kind of unitary language proficiency and interaction between the two.

However, I am not convinced that the two types of vocabulary knowledge are equal. Waring (1997), for instance, states that the proportion between receptive and productive vocabulary knowledge is approximately 50 per cent, whereas Milton (2009) contends that the proportion between the two ranges from 50 to 80 per cent. I agree with Nizonkiza and Van den Berg (2014), who believe that with 'such considerable variation' in the proportion of the two types of vocabulary, it is 'difficult to draw valid conclusions'. Therefore, as pointed out by Melka (1997) above, the actual 'truth' may lie between the second and the third tendencies. This provisional conclusion reached by researchers provides solid motivation for undertaking this current study, because there is such a wide gap between the two types of vocabulary knowledge.

As seen from the studies described above, researchers either adhere to a multi-dimensional representation of word knowledge or view receptive and productive knowledge as a continuum. They all accept the receptive and productive dimensions. Nevertheless, no clear distinct definition is provided for 'receptive' and 'productive' 
lexicon. In the present study, the term 'receptive' vocabulary knowledge is used to refer to the ability to understand a word when it is heard or seen and to retrieve its meaning. The term 'productive' vocabulary knowledge, on the other hand, is the knowledge one needs to produce a word while writing or speaking and then retrieving and producing its spoken and written form (Nation, 2011).

\section{The Present Study}

\subsection{Description of the Sample Population}

A total of 159 English majors in 12 groups (Note 3) at the Faculty of Pedagogy in a university in Azerbaijan participated in this study. It should be noted, however, that out of the 159 students who took part in the study in Year 1 and Year 2 (Note 4), only 110 completed both tests. Since testing students for research purposes is not customary at the university, it was made clear to the students that the tests were not part of the course requirements and, therefore, would have no impact on their academic record. It was also made clear to the participants that the data from the tests would be strictly confidential and used for research purposes only. The participants were all native speakers of Azerbaijani. Their English language proficiency ranged between pre-intermediate to intermediate. They all had to have passed an extremely competitive national entrance examination, including English language tests, in order to be admitted to the university.

In the first year, students are offered the following courses: Azerbaijan History, Psychology, Communication and Information Technology, Hearing and Pronunciation (English Phonetics) and General Linguistics. These courses make up 48 per cent of the whole programme and are conducted in Azerbaijani. In contrast, courses through the medium of English include Pre-Intermediate Reading and Speaking (a practical course that is taught through from the Pre-intermediate level in the first-year to the Advanced level in the fourth-year) and Communicative Grammar (a practical grammar course) take up 42 per cent of the whole programme. In these practical courses, the course materials - textbooks, supplementary materials such as newspaper materials, extra reading passages, graded readers, oral presentations, as well as written assignments - are mediated through English, although this is not always adhered to except for the examinations, which have to be written solely in English.

The sample can be further described taking into account university entrance examination scores and the number of years in which English was studied (see summary in Table 3). Information on the test-takers' university entrance examination scores as well as the number of years they studied English was collected during the bio-data gathering period. Participants sat two tests at the beginning of Year 1, which they also sat at the beginning of Year 2. These tests are described in the next section.

Table 3. Summary of the description of the sample

\begin{tabular}{llllll}
\hline & & Minimum & Maximum & Mean & SD \\
\hline $\begin{array}{l}\text { University } \\
\text { examination scores }\end{array}$ & entrance & 413 & 647 (out of 700) & 545 & 4.7 \\
$\begin{array}{l}\text { Number of years } \\
\text { English }\end{array}$ & studied & 1 & 11 & 6.6 & 2.1 \\
\hline
\end{tabular}

\subsection{Research Instruments}

Two instruments were used for the purposes of this study: the Vocabulary Levels Test (VLT) (Schmitt et al., 2001) and a vocabulary-size test of controlled productive ability (Laufer \& Nation, 1999). The VLT is used to measure learners' receptive vocabulary knowledge. It is a matching test in which the items are selected from the 2.000, $3.000,5.000$ and 10000 word bands and the academic word list (Coxhead, 2000) with 30 items in six clusters at each level.

Participants are instructed to match words to equivalent definitions. The test provides a rough estimate of a learner's 'receptive vocabulary size in the form of a vocabulary profile and the vocabulary size figures that it produces are quite reliable and robust' (Meara \& Alcoy, 2010: 222). The VLT has proved to be a useful tool in assisting teachers to diagnose the receptive vocabulary knowledge of their students and to track individual students' weaknesses, and thus help them. This is an important decision in terms of the cost-effectiveness of the use of class time, because certain words, for example, high-frequency words require different attention from low-frequency words (Laufer \& Nation, 1999). In the present study, the test by Schmitt et al. (2001) was used; 
however, because the students' language proficiency was far less than the 10.000 word band, samples from this word band were not included in the tests.

The vocabulary size test of controlled productive ability (CPVS) is a cued recall test. Laufer and Nation (1999: 37) define the term 'controlled productive ability' as

'the ability to use a word when compelled to do so by a teacher or researcher, whether in an unconstrained context such as a sentence writing task, or in a constrained context such as a fill in task where a sentence context is provided and the missing target word has to be supplied'.

In order to avoid other possible words - different from those targeted - Laufer and Nation (1999) provide the first two letters of the word to be supplied. The test measures 18 items at each of the 2.000, 3.000, 5.000, University Word List (UWL) and 10000 frequency levels. The test has been adjudged to be a very practical instrument, as it is easy to administer, to score and to interpret. For the same reason as explained above - since it was beyond what they could realistically achieve - the participants were not tested at the 10000 word band. As for the AWL/UWL, the students were not tested on these items in Year 2, since they are excluded in the formula used to estimate total vocabulary size (Laufer, 1998; Laufer \& Ravenhorst-Kalovski, 2010).

Once the data were collected, the following formula

$$
\text { Total score } \times 5.000 \div \text { Maximum score }
$$

as suggested by Laufer and Ravenhorst-Kalovski (2010) was used for calculating learners' vocabulary size estimates. It is worth noting that neither the participants nor their English-language instructors were informed about the results of the first study in order to avoid influencing the second-year content materials in any way. By doing so, I assume that it is also possible to evaluate the content of the teaching materials provided for these groups of learners during their instruction period.

\section{Results and Discussion}

In order to check the assumptions that are required to answer the research questions addressed so far, first, Explore was run in SPSS to verify whether the data were normally distributed. This did not prove to be the case and the Kolmogorov-Smirnov tests of normality show that the majority of the distribution is non-normal; but fortunately there are sufficient data at our disposal. In addition, ANOVAs are quite robust against departures from normality in the case of equal group sizes, which - by definition - is the case in Repeated Measures Designs (RMD). Explore was also run to see which students had extreme scores and the Box Plots indicated them. Without exception, these outliers are students performing relatively far above the average, so there was no reason to exclude them from the analyses to come.

4.1 Research Question 1: To what Extent Do the Receptive and Productive Vocabulary Sizes of English Majors Expand after a Year of Instruction?

To answer research question 1, concerning the extent of the growth of the vocabulary knowledge, the results from Year 1 and Year 2 of the same students were compared according to two types of vocabulary knowledge both receptively and productively. The data were examined using RMD with three within-subjects factors: time ( 2 levels: Year 1 and Year 2); reception versus production, and the frequency bands (2.000, 3.000 and 5.000). Scores on academic vocabulary were calculated separately. The RMD outcomes revealed that time (one academic year corresponding to 210 teaching hours $)$ is not significant $(F=0.168 ; p=0.682)$, implying that no general improvement in scores over time is observed.

However, the ANOVA revealed that the main effect for frequency (bands) $(\mathrm{F}=596.52 ; \mathrm{p}=0.000)$ and for year of study $(\mathrm{F}=9.09 ; \mathrm{p}=0.003)$ as well as the interaction between the two $(\mathrm{F}=3.35 ; \mathrm{p}=0.047)$ were statistically significant at the $\mathrm{p}<0.05$ level. In order to obtain a clearer picture and review the results in more detail, three-way interaction plots representing these interaction effects are presented in Figure 1 (receptive vocabulary test) and Figure 2 (productive vocabulary test). 


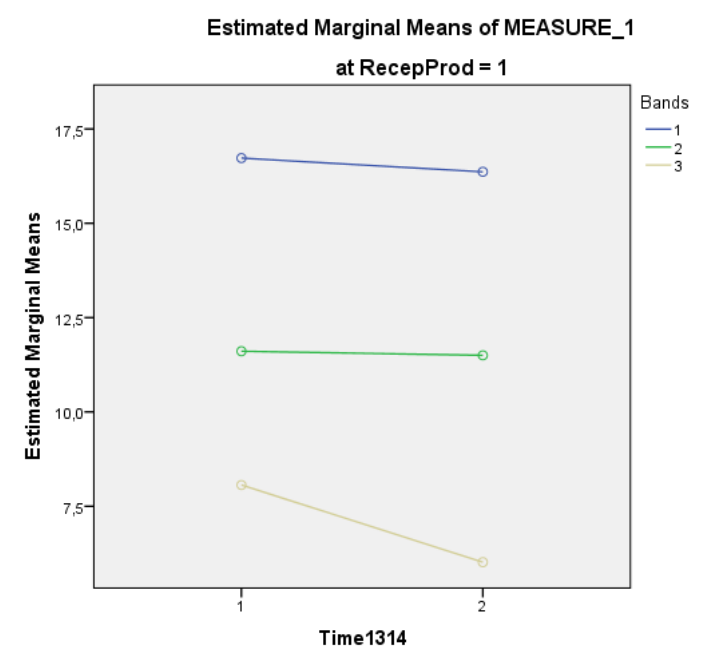

Figure 1. Three-way interaction plot for the Vocabulary Levels Test

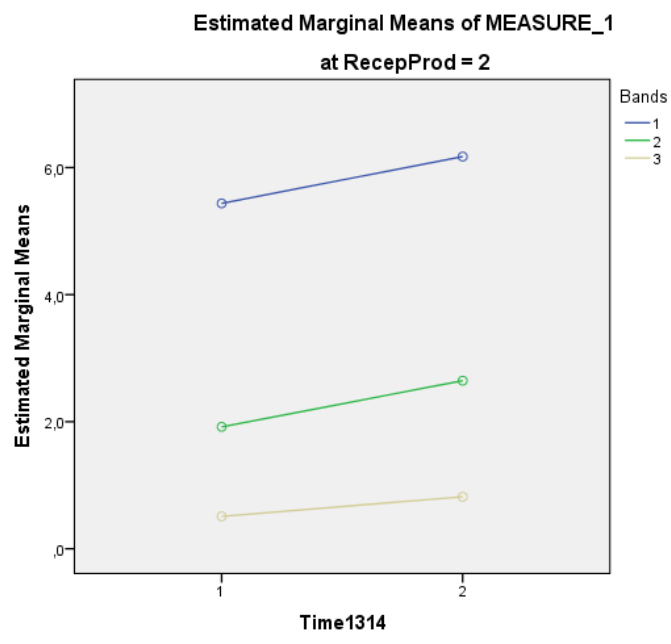

Figure 2. Three-way interaction plot for the vocabulary-size test of controlled productive ability

In terms of reception and production, it appears that there is a variation depending on the band. In comparison to receptive vocabulary size figures (mean values), productive vocabulary size figures increase, while the former decrease. To test whether these increases and decreases were statistically significant, t-tests were calculated. Means, standard deviations and t-test results are presented in Tables 4 and 5. The results show that the mean values for both types of test decrease as the frequency level decreases. The results (Table 4) also indicate a decrease in the receptive vocabulary, although this is not statistically significant, except for the band 5.000, where the decrease is significant at the 0.005 level. As opposed to the receptive test results, all increases in the productive vocabulary test scores (Table 5) are statistically significant at $\mathrm{p}<0.005$ level. The findings show that receptive vocabulary mean values are higher than those of productive vocabulary at all levels, which confirm previous studies (Fan, 2000; Laufer, 1998; Zhong \& Hirsh, 2009; Webb, 2008). However, the results on receptive knowledge contradict previous studies where significant expansion is reported (cf. Laufer, 1998; Zhong \& Hirsh, 2009) after a period of instruction. At the same time, the results at this level confirm Ozturk's (2012) study in which she reports on the absence of significant receptive vocabulary growth of the Turkish students after three years of instruction. Ozturk (2012) raises two reasonable possibilities for the lack of a significant difference in receptive scores: (1) either three years of instruction did not lead to sizeable gains since the participants in that study were 'advanced learners with most of the high-frequency vocabulary already in their stock'; or (2) the receptive vocabulary gains were not obtained in the data as these students were exposed to 
different kind of vocabulary from the kind of vocabulary measured by the VLT.

Estimating learners' vocabulary size in word families offers us the opportunity of obtaining comparable results and drawing relevant conclusions which may provide new insights for teaching vocabulary (Nizonkiza \& Van den Berg, 2014). This means that converting the raw mean values obtained from the descriptive analysis of the data into word families enables us to provide comparable figures. Table 5 shows that productive vocabulary has grown slightly in one year and, if we express the raw scores in terms of numbers of word families, the total 7.9 represents roughly 806 word families and 9.5 represents 974 word families.

If we compare the productive vocabulary sizes of Year 1 and Year 2 (Table 6), we can see that the students' productive vocabulary has increased by 21 per cent in one year of study. At the receptive level, however, vocabulary size figures (Table 4) show that the size did not increase at all; instead it decreased slightly in number when converted into word families. Looking at Tables 4, 5 and 6, we can see that the acquisition of the two types of vocabulary knowledge is not identical in size (in terms of numbers). That is, in one year of study, learners could add 168 word families to their productive vocabulary knowledge, whereas they could not gain any vocabulary in receptive knowledge: there was a 21 per cent (Note 6) increase in the productive vocabulary but a 0.10 per cent decrease in the receptive vocabulary.

Table 4. Comparison of receptive vocabulary size

\begin{tabular}{lllllll}
\hline Bands & $\begin{array}{l}\text { Year 1 } \\
(\mathrm{n}=116)\end{array}$ & \multicolumn{2}{l}{$\begin{array}{l}\text { Year 2 } \\
(\mathrm{n}=116)\end{array}$} \\
\cline { 2 - 7 } & Mean & $\mathrm{SD}$ & Mean & $\mathrm{SD}$ & t-value & $\mathrm{p}<0.05$ \\
\hline 2.000 & 16.7 & 6.6 & 16.3 & 7.0 & 0.39 & 0.346 \\
3.000 & 11.6 & 6.1 & 11.5 & 5.1 & 0.14 & 0.440 \\
5.000 & 8.0 & 6.3 & 6.0 & 4.3 & 2.79 & 0.002 \\
Total & 36.3 & 19 & 33.8 & 16.4 & 1.50 & 0.066 \\
\hline
\end{tabular}

Table 5. Comparison of productive vocabulary size

\begin{tabular}{lllllll}
\hline Bands & $\begin{array}{l}\text { Year 1 } \\
(\mathrm{n}=116)\end{array}$ & \multicolumn{2}{l}{$\begin{array}{l}\text { Year 2 } \\
(\mathrm{n}=116)\end{array}$} \\
\cline { 2 - 7 } & Mean & $\mathrm{SD}$ & Mean & $\mathrm{SD}$ & t-value & $\mathrm{p}<0.05$ \\
\hline 2.000 & 5.4 & 3.2 & 6.1 & 2.8 & 1.81 & 0.030 \\
3.000 & 1.9 & 1.9 & 2.6 & 1.4 & 3.17 & 0.0008 \\
$5 . .000$ & 0.6 & 0.8 & 0.8 & 0.9 & 2.59 & 0.0050 \\
Total & $7 . .9$ & 5.9 & 9.5 & 5.1 & 2.55 & 0.0054 \\
\hline
\end{tabular}

Table 6. Summaryof receptive and productive vocabulary sizes, Years 1 and 2

\begin{tabular}{lll}
\hline & Receptive & Productive \\
\hline Year 1 & 2.104 & 806 \\
Year 2 & 1.966 & 974 \\
Loss $/$ gain in \% & 00.10 & 21 \\
\hline
\end{tabular}

Research into second- or foreign-language receptive vocabulary increase through tertiary education, however, reports contradictory results. The vocabulary expansion of the learners involved in these studies fluctuates between 102 word families (Ozturk, 2012), 174 word families (Danilovic \& Grujic, 2014), 244 word families (Zhong \& Hirsh, 2009), and 200 words (Cobb \& Horst, 2000), 300 words (Schmitt \& Meara, 1997) and 1.326 words (Milton \& Meara, 1995).

Contrary to the abovementioned gain in size in these studies, the receptive vocabulary knowledge of Azerbaijani 
English majors decreased in size, although the findings are not statistically significant. Bearing in mind that one academic year comprises 15 weeks - corresponding to 210 teaching hours of practical English course apart from Communicative Grammar classes which contribute an additional 90 teaching hours - the average vocabulary gain per lesson was 1-2 word families productively, whereas there was no gain receptively. This is not an encouraging figure, since these students had sufficient academic hours at their disposal to have increased or developed their vocabulary knowledge.

These findings - that the students' receptive knowledge did not increase as opposed to the productive knowledge which increased after a year of studies - confirm earlier studies done by Waring (1997) and Zhong and Hirsh (2009), among others, according to whom receptive learning contributes to receptive knowledge, whereas productive learning results in increases in productive knowledge. However, others contradict others such as Chung and Nation (2004), according to whom teaching productively may lead to an increase in both receptive and productive vocabulary knowledge.

Moreover, Melka's (1997) lexical organisation perspective, which suggests that one needs to read the words in a text or hear them in order to be able to recall them ('external stimuli'), appears to have played a key role in these learners' decrease in receptive vocabulary knowledge. In other words, if participants in this study did not get sufficient input in the target language with regard to receptive vocabulary, and conversely received more productive tasks (such as doing translation-type grammar exercises and writing paragraphs), then this may account for the evidence of an increase in vocabulary knowledge productively rather than receptively. This could also be the case when students, after having achieved a certain vocabulary level receptively, have started to transfer their receptive into productive knowledge. This supports Melka's (1997) views in which she identifies the two types of vocabulary knowledge as a continuum on which gradually increasing vocabulary knowledge helps one to move from receptive to productive mastery.

The absence of an increase in receptive vocabulary knowledge could also be associated with the frequency with which the words found in the students' textbooks occur. This was tested by analysing the word bands of the words contained in the textbooks used by different university departments to teach first-year students. The results reveal that the main textbooks used in the classroom New English File (A2-B1) (Oxenden, Latham-Koenig \& Seligson, 2005) and Intermediate English (Gaibova \& Abdulrahimov, 2011) do not provide a good source of words from the most frequent 5.000 word families. In other words, lexical analysis of the texts, reading passages and vocabulary items in these textbooks (available at www.lextutor.ca) shows that words that belong to the first 5.000 band are inadequately represented. For example, 52 per cent of the word families were found to belong to the 1.000 word band, whereas 22 per cent of the word families came from the 2.000 word band. Words from the 3.000 and 5.000 word bands, respectively, accounted for only 10 per cent and 3.5 per cent of the words in the textbooks.

A study by Li and MacGregor (2010) indicates that although the VLT (Schmitt et al., 2001) which served as an instrument for this study is a useful tool for estimating language learners' receptive vocabulary knowledge, it is not possible to obtain accurate estimates. They therefore conclude that it is important that test words are 'representative of the vocabulary used in the linguistic environments relevant to the test-takers' (Li \& MacGregor, 2010). However, as Nation and Webb (2011) state, VLT is a knowledge test which attempts to identify those words known and those needing extra attention. Therefore, the test served its purpose in indicating that students engaged in this study required properly chosen lexical input tailored to their needs. Students have first to be presented with certain vocabulary items in order to then be tested on their vocabulary learning, that is, what vocabulary they have gained as a result of their studies. Given that these students were not previously exposed to the great majority of the tested words in their textbooks, and we were not testing their vocabulary learning, the modest indicator of the test results seems rather logical.

The tests actually served their purpose well: the poor test results indicate that these students need to pay more attention to words beyond the 2.000 word band. But how can we expect students to increase their vocabulary knowledge receptively if they do not encounter these words, as they are absent from the class textbooks?

\subsection{Research Question 2: What is the Ratio between Receptive and Productive Knowledge Increase?}

To answer research question 2 concerning the ratio between an increase in receptive and productive knowledge, the ratio between receptive and productive vocabulary for each group of participants (productive vocabulary size $* 100 \%$ /receptive vocabulary size: see Laufer, 1998) was calculated. With regard to the ratio between the two types of vocabulary knowledge, we can see that the receptive vocabulary is larger than the productive vocabulary, although the ratio between the two is different in the two groups studied. In Year 1 it is 38.3 per cent, whereas a year later it increases to 49.5 per cent. This means that the gap between the two types of vocabulary knowledge 
was narrower at a lower level of language proficiency. In terms of the gap between the receptive and productive vocabulary sizes, this outcome appears to contradict the result achieved by Laufer (1998), whereas it coincides with the outcome measured by Zhong and Hirsh (2009). In the case of the former, the gap between the two types of vocabulary knowledge increased in the more advanced group. However, in the latter case, although the gap between receptive and productive vocabulary sizes narrowed, there was a significant expansion of receptive vocabulary. In order to shed some light on these outcomes, two between-subject variables (BS-factors) - namely, university entrance points and number of years of study in English (Table 3bis) - were used.

Table 3bis. Summary of the description of the sample

\begin{tabular}{|c|c|c|c|c|}
\hline & Minimum & Maximum & Mean & SD \\
\hline $\begin{array}{l}\text { University entrance } \\
\text { scores }\end{array}$ & 413 & 647 (out of 700 ) & 545 & 4.7 \\
\hline Number of years studied English & 1 & 11 & 6.6 & 2.1 \\
\hline
\end{tabular}

They were first recoded based on the frequency distributions in order to have groups of approximately equal size. As shown in Table 3bis, the number of years of studying English shows various interaction effects and are highly significant at the $\mathrm{p}<0.003$ and $\mathrm{p}<0.007$ levels. The results indicate that those who studied English for eight years and more showed no increase in receptive vocabulary knowledge, whereas those students who studied the language for seven or fewer years showed an increase in both receptive and productive tests.

A provisional conclusion, however, seems to be that students with more than eight years of studying English behave in particular ways. That is, they have reached a point when receptive vocabulary knowledge develops into productive vocabulary knowledge, which is the reason why the gap between the two is narrow. In this connection, the RMD output indicates that those students with higher university examination points perform better than those with lower points $(<562$; see Table 3bis $)$.

Table 7. Pearson Correlation coefficient for individual test scores in Year 1 and Year 2

\begin{tabular}{lll}
\hline \multirow{2}{*}{ Receptive (Year 1) } & Productive (Year 1) & Productive (Year 2) \\
\cline { 2 - 3 } & $\begin{array}{l}\mathrm{r}=0.65 \\
\mathrm{p}<0.0001^{*}\end{array}$ \\
& & \\
Receptive (Year 2) & $\mathrm{r}=0.64$ \\
& & $\mathrm{p}<0.0001^{*}$ \\
\hline
\end{tabular}

*significant at $\mathrm{p}<0 . \overline{05 \text { level. }}$

Table 7 shows that there is a significant correlation between the two types of vocabulary knowledge among the same participants. This means that the learners who have a higher receptive vocabulary size also tend to have a higher productive vocabulary size. Bearing in mind the higher ratio of the more advanced group (Year 2 results), the results presented in Table 7 suggest that the higher one's receptive vocabulary size, the narrower the gap between it and the productive vocabulary size. The increasing ratio between the receptive and the productive vocabulary size figures indicates that at least some words that were learnt receptively enter their productive vocabulary. Even though this observation contradicts Laufer's (1998) findings, it confirms those of Zhong and Hirsh (2009).

\subsection{Research Question 3: Do English Majors Achieve the Expected Threshold Vocabulary Size of 4,000-5,000} Word Families after One Year of Instruction?

I now try to answer research question 3 concerning the expected increase in the receptive vocabulary knowledge to reach the vocabulary size of 4.000-5.000 word families after one year of instruction. The results of the present study indicate that the students could not reach the minimal vocabulary threshold as suggested by Laufer and Ravenhorst-Kalovski (2010). Taking into account the low receptive vocabulary size of 1.966 word families and a 
productive vocabulary size of 974 word families, it can be said that Azerbaijani students still lack the vocabulary needed to follow lectures in English effectively or to read and produce academic texts. Added to the fact that these students have to follow subject-specific compulsory and elective courses from Year 2 onwards, the level of their vocabulary is unsatisfactory.

Given the results obtained in this study, it would not be incorrect to suggest taking appropriate measures in order to help these learners to succeed in their academic studies. I have in mind a remedial or bridging course that can foster both receptive and productive vocabulary knowledge.

\section{Conclusions}

The present study explored the relationship between the receptive and productive vocabulary knowledge among Azerbaijani English majors. Its objectives were achieved by testing the same students at the beginning of both the first and the second year. The longitudinal data obtained from the current study from students from more than one year of academic study (corresponding to 210 academic hours per year) indicate that there was not a significant growth in their receptive vocabulary knowledge, whereas their productive vocabulary knowledge grew significantly. The current study also revelaed that contrary to the previously reported findings (cf. Laufer, 1998; Laufer \& Paribakht, 1998), learners' productive vocabulary grew faster than their receptive vocabulary knowledge which confirm the findings reported by Zhong and Hirsh (2009). It was argued that the possible reasons for the lack of growth in receptive vocabulary might be the deficiency in appropriate course materials. The students involved in this study did not frequently encounter the great majority of the word families outside the 2.000 word band in their textbooks and teaching materials, which might have caused the outcomes achieved in terms of the receptive vocabulary knowledge. Moreover, written examinations, doing translation-type grammar exercises and writing paragraphs, in other words, productive learning may account for the evidence of an increase in vocabulary knowledge productively rather than receptively. This could possibly also account for the students in this study starting to translate their receptive knowledge into their productive vocabulary, thus increasing their productive rather than their receptive vocabulary.

When converted to word families, the raw mean values also indicate that the students still lack the lexical threshold needed for minimal comprehension (see Laufer \& Ravenhorst-Kalovski, 2010). Taking into account that the students have one year only in which to develop and increase their vocabulary knowledge in order to be able to internalise academic texts, certain steps will have to be taken to remedy this situation.

Although this study employed a randomly selected large sample size, it exhibited abnormal distribution of the data. My not being schooled in testing students for gaining empirical data and my participation in the data-gathering process from a distance are among the limitations of this study. Testing students is a very difficult process in terms of administration, but without good and valid information about our learners' vocabulary knowledge, planning a well-balanced programme is not possible. It is therefore suggested that 'one-on-one' testing followed by 'group-administered' testing (Nation \& Webb, 2011) needs to be conducted in future. Perhaps, one-on-one testing and interviewing of the students after having them sit the tests may be a better way of delivering a valid result when we consider that test-takers do not always take tests seriously.

Furthermore, the lexical text coverage of the academic texts in the subject-specific textbooks of first-year English majors should be analysed for the level of vocabulary present. The analysis of the contents of subject-specific textbooks will create a basis for the development of a pedagogical word list of the most frequent words that these students are exposed to and which will meet their specific vocabulary needs. The relationship between the students' vocabulary size and the lexical text coverage of the subject-specific textbooks and their active production should be explored in order also to examine the relationship between these factors and to inform the teaching at this level so that steps can be taken to satisfy the students' academic needs and aspirations.

\section{Acknowlegments}

I would like to thank Professor Doctor Kris Van de Poel (University of Antwerp, Belgium) and Doctor Deogratias Nizonkiza (University of Burundi and North-West University, South Africa), who took the trouble to review the paper and to suggest changes. I would also like to express my gratitude to Professor Doctor Frans van der Slik (Radboud University, Nijmegen), who kindly analysed and interpreted the data statistically. Without Frans's insights this paper would not have made such a strong case.

\section{References}

Alderson, J. C. (2005). Diagnosing Foreign Language Proficiency. London: Continuum.

Chung, T. M., \& Nation, I. S. P. (2004). Identifying technical vocabulary. System, 32, 251-263.

Cobb, T. \& Horst, M. (2000). Vocabulary sizes of some City University students. City University (HK) Journal of 
Language Studies, 1, 59-68.

Coxhead, A. (2000). A new academic word list. TESOL Quarterly, 34(2), 213-238.

Crystal, D. (1987). How many words? English Today, 11-14.

D’Anna, C. A., Zechmeister, E. B., \& Hall, J. W. (1991). Toward a meaningful definition of a vocabulary size. Journal of Reading Behaviour, 21, 109-122.

Danilovic, J. R., \& Grujic T. S. (2014). Vocabulary growth at tertiary level: How much progress can Serbian EFL learners make in a year? Зборник Института за Педагошка Истраживаваньа, 46(1), 200-218.

Fan, M. (2000). How big is the gap and how to narrow it? An investigation into the active and passive vocabulary knowledge of L2 learners. RELC Journal, 105-119.

Gaibova, M., \& Abdulrahimov, E. (2011). Intermediate English. Baku: East-West.

Goulden, R., Nation, I. S. P., \& Read, J. (1990). How large can a receptive vocabulary be? Applied Linguistics, 11, 341-363.

Hajiyeva, K. (2014). Receptive and productive vocabulary level needs: An Empirical study of Azerbaijani English majors. International Journal of Learning, Teaching and Educational Research, 9(1), 51-65.

Henriksen, B. (1999). Three dimensions of vocabulary development. Studies in Second Language Acquisition, 21(2), 303-317.

Laufer, B. (1992). How much lexis is necessary for reading co mprehension? In H. Bejoint \& P. Arnaud (Eds.), Vocabulary and Applied Linguistics (pp. 126-132). United Kingdom: Macmillan.

Laufer, B. (1998). The development of passive and active vocabulary in a second language: Same or different? Applied Linguistics, 12, 255-271.

Laufer, B., \& Nation, I. S. P. (1999). A vocabulary-size test of controlled productive ability. Language Testing, $16(1), 33-51$.

Laufer, B., \& Paribacht, T. S. (1998). The relationship between passive and active vocabularies: Effects of language learning context. Language Learning, 48, 365-391.

Laufer, B., \& Ravenhorst-Kalovski, G. C. (2010). Lexical threshold revisited: Lexical text coverage, learner's vocabulary size and reading comprehension. Reading in a Foreign Language, 15-30.

Li, L., \& McGregor, L. J. (2010). Investigating the receptive vocabulary size of university-level Chinese learners of English: How suitable is the levels test? Language and Education, 24(3), 239-249.

Meara, P. M. (1990). A note on passive vocabulary. Second language Research, 6(2), 150-154.

Meara, P. M. (1996). The dimensions of lexical competence. In G. Brown, K. Malmkjaer \& J. Williams (Eds.), Competence and Performance in Language Learning. Cambridge: Cambridge University Press.

Meara, P. M. \& Alcoy, J. C. O. (2010). Words as species: An alternative approach to estimating productive vocabulary size. Reading in a Foreign Language, 22(1), 22-236.

Melka, F. (1997). Receptive vs. productive aspects of vocabulary. In N. Schmitt \& M. McCarthy (Eds.), Vocabulary: Description, Acquistion and Pedagogy. (pp. 82-102). Cambridge: Cambridge University Press.

Melka-Teichroew, F. J. (1982). Receptive versus productive vocabulary: A survey. Interlanguage Studies Bulletin, $6(2), 5-29$.

Milton, J. (2009). Measuring Second Language Vocabulary Acquisition. Bristol: Multilingual Matters.

Milton, J., \& Meara, P. (1995). How do periods abroad affect vocabulary growth in a foreign language? ITL Review of Applied Linguistics, 107-108, 17-34.

Milton, J., \& Treffers-Daller, J. (2013). Vocabulary size revisited: The link betweenvocabulary size and academic achievement. Applied Linguistics Review, 4(1), 151-172.

Nation, I. S. P. (1990). Teaching and Learning Vocabulary. New York: Newbury House.

Nation, I. S. P. (2006). How large a vocabulary is needed for reading and listening? The Canadian Modern Language Review, 63, 59-82.

Nation, I. S. P. (2011). Learning Vocabulary in Another Language. Cambridge: Cambridge University Press.

Nation, I. S. P., \& Beglar, D. (2007). A vocabulary size test. The Language Teacher, 31(7), 9-12. 
Nation, I. S. P., \& Waring, R. (1997). Vocabulary size, text coverage and word lists. In N. Schmitt \& M. McCarthy (Eds.), Vocabulary: Description, Acquisition, and Pedagogy (pp. 6-17). Cambridge: Cambridge University Press.

Nation, I. S. P., \& Webb, S. (2011). Researching and Analyzing Vocabulary. United States: Heinle, Cengage Learning.

Nizonkiza, D., \& Van den Berg, K. (2014). The dimensional approach to vocabulary testing: What can we learn from past and present practices? Stellenbosch Papers in Linguistics Plus, 43, 1-14.

Oxenden, C., Latham-Koenig, C., \& Seligson, P. (2004). New English File (Pre-intermediate). Oxford: Oxford University Press.

Ozturk, M. (2012). Vocabulary growth of the advanced EFL learner. The Language Learning Journal, 1-16.

Read, J. (1997). Vocabulary and testing. In N. Schmitt \& M. McCarthy (Eds.), Vocabulary: Description, Acquistion and Pedagogy (pp. 303-321). Cambridge: Cambridge University Press.

Read, J. (2000). Assessing Vocabulary. Cambridge: Cambridge University Press.

Schmitt, N. (2008). Instructed second language vocabulary learninng. Language Teaching Research, 12(3), 329-363.

Schmitt, N. (2010). Vocabulary in Language Teaching. New York: Cambridge University Press.

Schmitt, N., \& Meara, P. (1997). Researching vocabulary through a word knowledge framework: Word associations and verbal suffixes. Studies in Second Language Acquisition, 20, 17-36.

Schmitt, N., Schmitt, D., \& Clapham, C. (2001). Developing and exploring the behavior of two new versions of the Vocabulary Levels Test. Language Testing, 18(1), 55-88.

Takala, S. (1984). Evaluation of students' knowledge of English vocabulary in the Finnish comprehensive school. Reports of the Institute of Educational Research, 350. Jyväskulä: Finland.

Waring, R. (1997). A comparison of the receptive and productive vocabulary sizes of some second-language learners. Immaculata (Notre Dame Seishin University, Okayama), 1, 53-68.

Webb, S. (2008). Receptive and productive vocabulary sizes of L2 learners. Studies in Second Language Acquisition, 30(1), 79-95. http://dx.doi.org/10.1017/S0272263108080042

Zhong, H., \& Hirsh, D. (2009). Vocabulary growth in an English as a foreign language context. University of Sydney Papers in TESOL, 4, 85-113.

\section{Notes}

Note 1. A word family consists of a base word and all its derived and inflected forms that can be understood without having to learn each form separately.

Note 2. 'Text coverage' means the number of running words in a text (Laufer \& Ravenhorst-Kalovski, 2010).

Note 3. All university entrants at AUL are organised in groups (13-16 students per group) according to their university entrance points at the beginning of the first year. For this study 12 such groups were recruited.

Note 4. Along the study, 'Year 1' is used to refer to the receptive and productive tests conducted at the beginning of the first year and simultaneously, 'Year 2' is used to refer to the second two tests conducted after one year of instruction.

Note 5. We filled in the missing 4.000 level by averaging the scores received at the 3.000 and 5.000 word level. The score at each frequency level represents an approximate knowledge of 1,000 words, except the first 2.000, where the score represents knowledge of 2,000 words. Accordingly, if a learner received 28 on the second 1.000 , 22 on the third, and 8 on the fifth, his or her score would be $28+28+22+15+8=101$ (The figure 28 appears twice as it represents 2.000 words, whereas the other scores represent 1.000 words each. Figure 15 is the average of 22 and 8). Since each frequency level has 30 items, the maximum score, which represents knowledge of 5.000 words, would be $30 \times 5=150$. The score in our example would represent $101 \times 5.000 \div 150=3.366$ word families

Note 6 . The gain or loss in the receptive and productive vocabulary size figures were calculated by subtracting the entrance level figure (Year 1 estimate) from the exit level figure (Year 2 estimate) and dividing it by the entrance level. For example, 974 (exit level, Year 2) - 806 (entrance level, Year 1) $\div 806$ (entrance level) = Gain 


\section{Copyrights}

Copyright for this article is retained by the author(s), with first publication rights granted to the journal.

This is an open-access article distributed under the terms and conditions of the Creative Commons Attribution license (http://creativecommons.org/licenses/by/3.0/). 